\title{
Density Dependent Competitive Interactions between Weedy Rice (Oryza Sativa F. Spontanea) and Cultivated Rice in Sri Lanka
}

\author{
Karunarathna KDK, Somaratne S and Weerakoon SR* \\ Department of Botany, Open University of Sri Lanka, Sri Lanka
}

Submission: March 14, 2017; Published: April 12, 2017

"Corresponding author: Weerakoon SR, Department of Botany, Open University of Sri Lanka, P.O. Box 21, Nawala, Sri Lanka, Tel: +94714933922; Fax: +94 112806577; Email: shyamaweerakoon@gmail.com

\begin{abstract}
Weedy rice (Oryza sativa f. spontanea) is a major threat in many rice-growing areas in tropical Asia including Sri Lanka since 1990s. Even though numerous scientific investigations on origin, diversity, distribution and controlling technique of weedy rice is available, there is a need in research pertaining to interactions of weedy rice with cultivated rice varieties under local situations. A green-house experiment was conducted at The Open University of Sri Lanka using an improved-cultivated rice variety (Bg379-2) with varying ratios of cultivated: a black-hulled weedy rice bio-type (0, 20, 40, 6080 100/pot). Influence of weedy rice on growth and yield of Bg379-2 was assessed through 2, 4, 6 and 8 weekly measurements of plant height and number of tillers. Dry shoot-and root- biomass were determined through oven-dried uprooted plants at 8 weeks after sowing (8WAS). Yield components of Bg379-2 including 100 grain weight/plant, number of panicles/plant, number of grains/panicle and yield weight/plant were calculated. Data were statistically analyzed using SAS Ver. 9.0. Significant interactions between weedy rice bio-type and Bg379-2 were apparent after 6 weeks after sowing (WAS). A yield loss of 30\% was observed even when at a percentage of 20 of weedy rice at $20 /$ pot. At $80 \%$ plants/pot, weedy rice resulted in $90 \%$ loss of yield of variety Bg379-2. Further research is recommended to determine weedy rice density on growth and yield components of different new improved rice varieties.
\end{abstract}

Keywords: Competition; Oryza Sativa F. Spontanea; Yield loss; Sri lanka; Weedy rice

\section{Introduction}

Weedy rice (Oryza sativa f. spontanea) has become a major threat in many rice-growing areas. This weed is widely distributed in rice growing areas in the world, particularly in South and SouthEast Asia, South and North America, and Southern Europe [1-3] and leads to high production costs as well as considerable yield reduction [4]. In general, weedy rice (WR) populations diminish farmer's income both quantitatively and qualitatively [5]. At present, WR has reached to a competitive level of infestation to threaten the sustainability of rice cultivation especially in Asian countries.

The flower morphology and brief period of pollen viability of cultivated rice is an adaptation to being a predominantly selfpollinating crop. The wild rice, on the other hand, differ from cultivated rice by having a greater ability for out-crossing having longer styles, stigmas, filaments and anthers, and pollen viability as twice as cultivated rice [1]. Weedy rice, although systematically classified under the same species as cultivated rice, is strongly characterized by its very high seed shattering property and seed dormancy, which apparently enhance the distribution of this species and continuous enrichment of soil seed bank with WR seeds [6].

In Sri Lanka, WR has become a major problem since late 1990 affecting growth and yield of cultivated rice amounting to $30-40 \%$ yield loss (about 1,600-2,000kg/ha) despite farmers investing Sri Lankan Rs. 5000-8000/ha for herbicides [7,8]. The growth and competitive ability of WR vary considerably among populations due to differences in plant height, leaf area, or biomass [3]. According to [9], one to three plants $/ \mathrm{m} 2$ of WR is the threshold infestation level that is required to prevent yield losses in rice, whereas the corresponding density for barnyard grass (E. crusgalli) is estimated as $5-10$ plants $/ \mathrm{m} 2$.

As labor and or water costs rises in many Asian countries, transplanting of rice seedlings, the well adapted crop establishment method, has being replaced by direct seeding (DS) where the 
emergence of WR assumed to have initiated [10]. Direct seeded rice ecosystems provide environments conducive for the emergence and propagation of WR as compared to transplanted rice having standing water that suppress the emergence of WR at the early stages of the crop [11]. Furthermore, selective herbicides to control WR are yet to be identified. Thus, managing WR is a challenging problem for farmers because of its morphological and physiological similarities to cultivated rice. Weedy rice can cause severe yield losses to cultivated rice in relation to the density, type of weedy plants and cultivated varieties [12]. In Malaysia WR caused rice yield loss of $60 \%$ to $80 \%$ under moderate (15-20 weedy rice panicles $/ \mathrm{m}^{2}$ ) to high (21-30 panicles $/ \mathrm{m}^{2}$ ) infestations [4]. Short varieties are usually more susceptible to WR competition than tall ones [13]. Some studies have been conducted to assess the effects of different weed densities. [14] reported that density of 11 weedy rice plants $\mathrm{m}-2$ led to considerable yield loss of $43 \%$. Although a number of scientific investigations on WR origin, diversity, distribution and technique for control are available, researches pertaining to interactions of WR with new improved rice varieties under local conditions are inadequate. In spite of the importance of WR rice as a noxious weed, there is a scarcity of information is available in Asia on the magnitude of the yield and other growth parameters of cultivated rice and WR rice.

An expansion in the area under direct-seeded rice systems in the near future in Asia is expected due to labor and water deficiency $[15,16]$. In these systems, WR infestation will increase because of the absence of the suppressive effect of standing water during crop emergence. Therefore, it is important to study the effect of the degree of WR infestation on the growth and yield of cultivated rice. The proper understanding of the density dependent competitive interaction between cultivated and WR rice is essential in providing baseline information for farmer-awareness programs and strengthening farmer capabilities of WR management in rice fields in particular, for the preparation of guidance and justification of the costs of WR prevention and control measures. The present study was carried out with the objective to quantify the competitive performance between WR and a new improved rice variety as a function of rice yield and selected growth parameters.

\section{Methodology}

Experiments were conducted at The Open University of Sri Lanka. The improved-cultivated rice variety Bg379-2 and a black hulled WR bio-type collected from Matara District in Southern Province of Sri Lanka served as experimental materials. The rice variety Bg379-2 was chosen for the reason that it has been widely cultivated in the District of Matara. The soils were collected from the areas from the rice field where weedy rice bio-type was collected. Collected soils were passed through a $2 \mathrm{~mm}$ sieve and placed in cement pots of $30 \times 30 \times 30 \mathrm{~cm}$. There were no holes in the pots. The weedy rice and cultivated rice (cv. Bg379-2 and a commonly grown variety in Matara District and black hulled WR bio-type) were grown in a replacement series design at proportions (cultivated rice: weedy rice) (\%) of 0:100, 20:60, 40:60, 60:40, and 80:20 plants in a pot. The population was grown in $100 \%$ proportion considered as no completion and the rest represent the different degrees of completions (Figure 1).

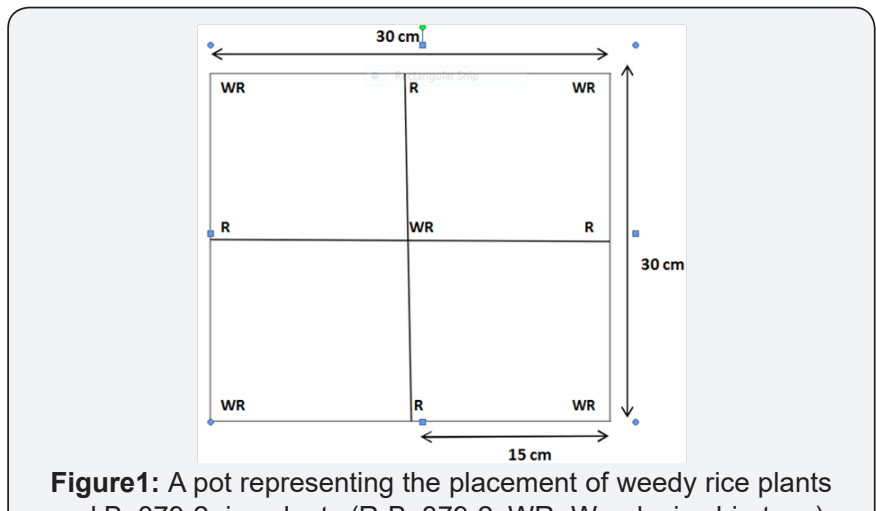
and Bg379-2 rice plants (R-Bg379-2, WR- Weedy rice bio-type).

The plants were fertilized with urea at a rate of $100 \mathrm{~kg} / \mathrm{ha}$ at 14,28 , and 60 days after sowing and pots were maintained at field capacity by irrigating regularly. After crop emergence, $2 \mathrm{~cm}$ depth of water was maintained until crop maturity. Insect or disease problems were not observed during the experimental period and, therefore no control measures were undertaken.

The influence of WR plants on growth and development of Bg379-2 was assessed through 2, 4, 6 and 8 weekly measurements of important agro-morphological characters, plant height and number of tillers. The dry shoot- and root- biomass were determined through oven drying at $70 \mathrm{~b}{ }^{\circ} \mathrm{C}$ for $72 \mathrm{~h}$ of uprooted randomly selected plants at 8WAS. At harvesting stage, the yield components of both Bg379-2 and WR bio-type, including 100 grain weight/ plant, number of panicles/plant, number of grains/panicle and yield weight/plant were estimated(data were not given for WR biotype). Collected data were statistically analyzed using [17]. One way analysis of variance (ANOVA) carried out comparing the treatment means were compared using of Tukey's studenize test (HSD) and difference at $\mathrm{p} \leq 0.05$ was considered as statistically significant.

\section{Results and Discussion}

Table 1: Plant height of Bg379-2 grown under different densities of weedy rice at different weeks after sowing (WAS). (Means (+SE) within a column followed by the same letter(s) are not significantly different at $p \leq 0.05$ ).

\begin{tabular}{|c|c|c|c|c|}
\hline \multicolumn{2}{|c|}{$\begin{array}{c}\text { Plant Height (cm) } \\
\text { Rice Ration (\%) }\end{array}$} & 2WAS & 4WAS & 6WAS \\
\hline 0 & $27.0(0.31) \mathrm{c}$ & $46.4(0.12) \mathrm{a}$ & $68.7(0.32) \mathrm{a}$ \\
\hline 20 & $28.4(0.15) \mathrm{a}$ & $45.8(0.21) \mathrm{ab}$ & $65.1(0.29) \mathrm{b}$ \\
\hline
\end{tabular}




\section{Agricultural Research \& Technology: Open Access Journal}

\begin{tabular}{|c|c|c|c|c|}
\hline 40 & $28.0(0.47) \mathrm{ab}$ & $45.1(0.21) \mathrm{c}$ & $63.9(0.31) \mathrm{c}$ & $76.8(0.23) \mathrm{b}$ \\
\hline 60 & $27.4(0.15) \mathrm{bc}$ & $41.2(0.12) \mathrm{d}$ & $58.6(0.15) \mathrm{d}$ & $70.9(0.29) \mathrm{c}$ \\
\hline 80 & $27.3(0.15) \mathrm{c}$ & $45.5(0.26) \mathrm{bc}$ & $56.8(0.31) \mathrm{e}$ & $64.9(0.40) \mathrm{d}$ \\
\hline Critical value & 0.7169 & 0.9841 & 0.7648 & 0.7342 \\
\hline
\end{tabular}

The effect of WR density on Bg379-2 was evidenced by the significant differences observed in plant height and tiller number from 6 WAS onwards (Table1). Comparatively, there was a considerable decrease in plant height at 8 WAS (from $81.9 \mathrm{~cm}$ in the control to $64.9 \mathrm{~cm}$ at the highest WR density: $80 \mathrm{WR}$ plant/pot) and number of tillers/plant (from 35 in the control to 22.1 at the highest WR percentage; $80 \%$ WR plant/pot). Even at the lowest WR density tested (1WR plants/ pot), the effect is apparent in both parameters (Table 1).

In the present study, the varying densities of WR indicated a considerable reduction in growth parameters and yield components of improved-cultivated rice variety Bg379-2 under the green-house conditions. The plant height and number of tillers of rice plants seem to be less affected at 2 and 4 WAS at different percentages of WR/pot. However, the effect of varying percentages of WR on root and shoot biomass indicated decreasing trends for Bg379-2. This finding agreed with [17] who suggested that the decreasing trends are due to the shading effect of WR, and observed that different sunlight regimes and shoot biomass (stem and leaf biomass) of cultivated rice declined by $57 \%$ and $72 \%$ when grown in $50 \%$ and $75 \%$ of shade, respectively. On this basis, it could be suggested that the decrease of dry matter accumulation in cultivated rice variety Bg379-2 is attributed to competition of WR over cultivated rice for capturing the light. The effect of WR percentage on Bg379-2 was obvious on root biomass ( $65 \%$ reduction) than shoot biomass (60\% reduction) at 8 WAS under the density at 4 plants/pot (Table 2) (Figure 2).

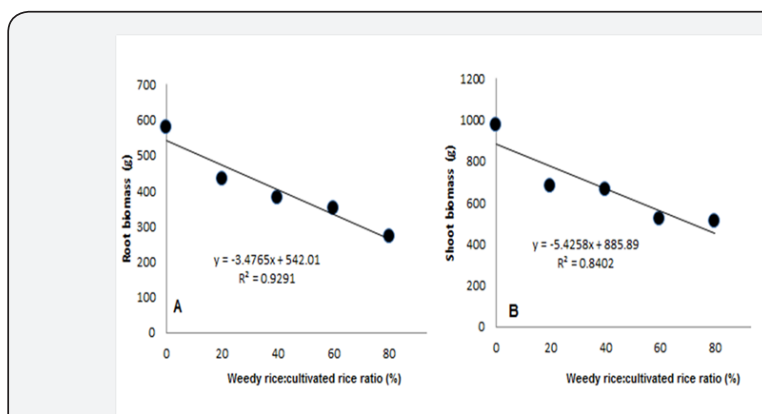

Figure 2: Relationship between the weedy rice: cultivated rice ratio. A. Root biomass and B. Shoot biomass.

Table 2: Root and shoot biomass of Bg 379-2 grown under different densities of weedy rice at 8WAS. (Means (+SE) followed by the same letter(s) in a column are not significantly different at $p \leq 0.05$.

\begin{tabular}{|c|c|c|}
\hline Weedy Rice: Cultivated Rice Ratio (as \%) & Root Biomass (g/plant) & Shoot Biomass (g/plant) \\
\hline 0 & $57.81(0.01) \mathrm{a}$ & $67.28(0.04) \mathrm{a}$ \\
\hline 20 & $43.41(0.03) \mathrm{b}$ & $66.84(0.01) \mathrm{ab}$ \\
\hline 40 & $37.96(0.05) \mathrm{c}$ & $51.96(0.02) \mathrm{ab}$ \\
\hline 60 & $35.09(0.03) \mathrm{b}$ \\
\hline 80 & $27.20(0.02 \mathrm{e}$ & $50.97(0.04) \mathrm{b}$ \\
\hline Critical vale & 0.8074 & 323.66 \\
\hline
\end{tabular}

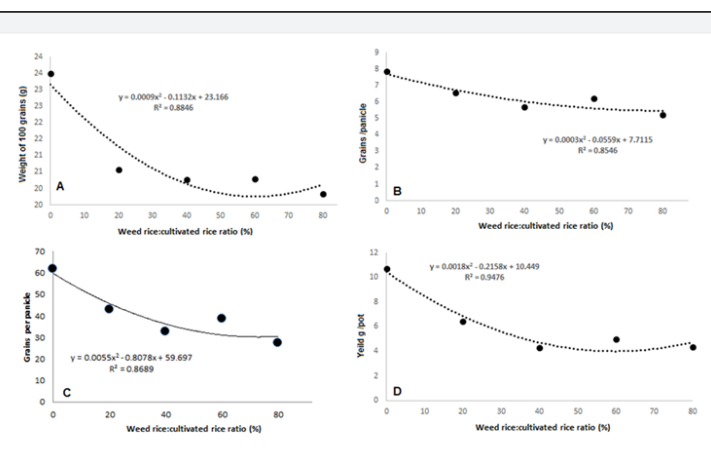

Figure 3: Relationship between the weedy rice: cultivated rice ratio and yield components. A. 100 grain weight/plant (g/plant),

B. Number of grains/panicle, C. Number of panicles/plant, and D. yield (g/plant) of improved-cultivated rice variety, Bg379-2.

The effect of density of WR plants on Bg379-2 on the root biomass at 8WAS even under the density of one WR plant/pot suggests that WR roots may exert considerable competitive effect over the improved rice variety and interfere with the nutrient uptake. This finding is further supported by results of detailed comparative study with other weed species as well as with other improved rice varieties carried out by [18]. The overall effect of different WR densities on Bg379-2 was more apparent in the relationships observed for yield components; 100 grain weight/ plant (Figure 3A), grains/panicle (Figure 3B), panicle density (panicles/plant) (Figure 3C) and yield (Figure 3D) (Table 3). Even under lower values of WR densities (1WR plants/pot), there were substantial difference in 100 grain weight (ranged from $61.06 \mathrm{~g}$ / plant to $87.55 \mathrm{~g} / \mathrm{plant}$ ), grains/panicle (ranged from 33.0to42.0), panicle density (from 5/plant to 10/plant) and yield reducing from $47.76 \mathrm{~g} /$ plant to $68.01 \mathrm{~g} /$ plant. These results indicated that there was a substantial effect of the presence of WR plants on panicle formation and grain filling of the improved rice cultivar, Bg379-2. The relationship observed between the WR density and the yield 
of Bg379-2 showed a yield loss of $90 \%$ ((calculated from data available in (Table 3)) at weedy rice density of 4 WR plants/pot. Comparatively higher $(90 \%)$ yield loss of the cultivated rice even at

Table 3: Yield components of Bg379-2 grown under different densities of weedy rice. (Means (+SE) within a column followed by the same letter(s) are not significantly different at $p=0.05$ ).

\begin{tabular}{|c|c|c|c|c|}
\hline $\begin{array}{c}\text { Weedy rice: Cultivated } \\
\text { Rice Ratio (as \%) }\end{array}$ & $\begin{array}{c}\text { 100 Grain Weight (g/ } \\
\text { plant) }\end{array}$ & Grains/Panicle & Number of Panicles/Plant & Yield (g/plant) \\
\hline 0 & $87.55(0.01) \mathrm{a}$ & $42.0(0.01) \mathrm{a}$ & $10.0(0.01) \mathrm{a}$ & $68.01(0.01) \mathrm{a}$ \\
\hline 20 & $61.06(0.00) \mathrm{b}$ & $33.0(0.02) \mathrm{ab}$ & $9.0(0.02) \mathrm{b}$ & $47.76(0.01) \mathrm{b}$ \\
\hline 40 & $29.87(0.01) \mathrm{c}$ & $32.0(0.02) \mathrm{b}$ & $6.0(0.02) \mathrm{d}$ & $21.04(0.02) \mathrm{e}$ \\
\hline 60 & $15.59(0.02) \mathrm{d}$ & $28.0(0.03) \mathrm{b}$ & $8.0(0.03) \mathrm{c}$ & $18.52(0.03) \mathrm{d}$ \\
\hline 80 & $6.97(0.01) \mathrm{e}$ & $27.0(0.05) \mathrm{b}$ & $5.0(0.00) \mathrm{e}$ & $6.27(0.05) \mathrm{c}$ \\
\hline Critical value & 0.5131 & 1.7102 & 1.5 & 2.32 \\
\hline
\end{tabular}

As present study revealed, the yield loss of the cultivated rice due to the presence of WR is comparatively higher even at WR density at $1 \mathrm{WR}$ plants/pot. Similarly [14] has made observations with $1 \mathrm{WR}$ plants/pot and observed a yield loss of about $43 \%$. These evidences suggest farmers to take controlling measures even at the lowest WR density. However, it is proposed to extend this study to other popular improved-cultivated rice varieties to facilitate the understanding of the differential interactions of WR and cultivated rice and to define action thresholds for WR. A study with two WR variants (WR1 and WR2) revealed that, WR1 reduced the grain yield of cultivated rice by $30 \%$ and $47 \%$ at densities of 4 and 8 WR plants/pot respectively. The values for WR2 were $66 \%$ and $81 \%$ respectively [17]. Weedy rice, with its deep root system and height found to interfere with the nutrition and light availability to the new improved rice. In addition, WR, as a newly invading plant to the rice soils may have developed tolerance and adaptability to limited resources for survival and to compete with other plants.

Several studies have shown that competition effects of rice and WR rice are also closely related to the interference duration [19]. Combining the effects of WR density and duration of competition, [12] observed a $50 \%$ yield reduction at $24 \mathrm{WR}$ plants $/ \mathrm{m}^{2}$ competed with the crop during the first 40 days after emergence. With the same initial density, the yield loss reached $75 \%$ in the case of season-long competition. In a green-house experiment, significant effects on rice plant growth were reported only at the competition longer than 70 days, starting from the emergence [20,21]. In studies of competition using cultivar Mars, inter-varietal competition resulted as being important than intra varietal competition, with the WR acting as the dominant competitor [22]. Considering the yield components, the effect of plant density seems to be significant on the number of rice panicles/plant and florets/panicle, while the percent of filled florets and the grain weight do not seem to be influenced by this parameter $[23,24]$ have observed that interference between rice and WR commenced three weeks after rice emergence, but was not affected by an increase of the nitrogen rate from $100 \mathrm{to} 150 \mathrm{~kg} / \mathrm{ha}$. According to their study a density of $40 \mathrm{WR}$ plants $/ \mathrm{m}^{2}$ resulted in a reduction of $46 \%$ and $58 \%$ in Ariete and Thaibonnet rice varieties, respectively. the weedy rice density at $1 \mathrm{WR}$ plants/pot could be attributed to the presence of weedy rice (Figure 3D) (Table 3) (Figure 3).

\section{Conclusion}

The findings of the present study led to conclude that infestation of WR even at low density of $1 \mathrm{WR}$ plant/pot affected the growth of the new improved rice variety, Bg379-2 leading to a considerable loss in yield (30\%). However, further research is needed to determine the impact of crop management on the competitiveness of WR under field conditions representing different climatic conditions $[25,26]$.

\section{Acknowledgement}

Authors wish to acknowledge the Open University of Sri Lanka for the financial support given to carry out this research.

\section{References}

1. Mortimer M, Pandey S, Piggin C (2000) Weedy rice: approaches to ecological appraisal and implications for research priorities. Wild and Weedy Rice in Rice Ecosystems in Asia -A review. In: Baki BB, Chin DV, Mortimer M (Eds.), International Rice Research Institute, Los Banos, Philippines, pp. 97-105.

2. Noldin JA (2000) Red rice status and management in Americas. Wild and weedy rice in rice ecosystems in Asi-A review. In: Baki BB, Chin DV, Mortimer M (Eds.), International Rice Research Institute. Los Baños, Philippines, pp. 21-24.

3. Chauhan BS, Johnson DE (2010) The role of seed ecology in improving weed management strategies in the tropics. Advances in Agronomy 105: 221-262.

4. Chauhan BS (2012) Weedy rice (Oryza sativa) II. Response of weedy rice to seed burial and flooding depth. Weed Science 60(3): 385-388.

5. Azmi M, Karim R (2008) Weedy Rice-Biology, Ecology and Management. MARDI Publications, Malaysia.

6. Oka HI (1988) Origin of cultivated rice. Japan Science Society Press, Tokyo.

7. Baltazar AM, Janiya JD (2000) Weedy Rice in the Philippines. Wild and Weedy Rice in Rice Ecosystems in Asia a Review. In: Baki BB, Chin DV, Mortimer M (Eds.), International Rice Research Institute, Los Banos, Philippines, pp. 75-76.

8. Marambe B, Amarasinghe L (2000) Weedy rice in Sri Lanka. Wild and Weedy Rice in Rice Ecosystems in Asia-a review. In: Baki BB, Chin DV, Mortimer M (Eds.), International Rice Research Institute, Philippines, pp. 79-82.

9. Abeysekera AS, Herath HMS, Wickreme UB, Johnson DE (2010) Improving crop establishment and reducing loss from weeds in direct- 
seeded rice in Sri Lanka. Research to Impact: Case studies for Natural Resources Management for Irrigated rice in Asia. IRRI, Los Banos, The Philippines, pp. 151-166.

10. Smith RJ (1988) Weed threshold in southern US rice, (Oryza sativa). Weed Technology 2(3): 232-241.

11. Pandey S, Velasco L (2005) Trends in crop establishment methods in Asia and research issues. In: Toriyama K, Heong KL, Hardy B (Eds.) Rice is Life: Scientific Perspectives for the $21^{\text {st }}$ Century. Proceeding of the Word Rice Research Conference, Tsukuba, Japan, pp. 178-181.

12. Chauhan BS, Johnson DE (2010) Weedy rice (Oryza sativa L). I. Grain characteristics and growth response to competition of weedy rice variants of five Asian countries. Weed Science 58: 374-380.

13. Fischer AJ, Ramirez A (1993) Red rice (Oryza sativa) competition studies for management decisions. International Journal of Pest Management 39(2): 133-138.

14. Kwon SL, Smith RJ, Talbert RE (1991) Interference of red rice (Oryza sativa L) densities in rice (Oryza sativa L). Weed Science 39(2): 169174

15. Abud JK (1989) Efeitos competitivos do arroz vermelhonos components do rendimento e rendimento degraos em casca na cultivar de arroz BRIGRA 412. Lavoura Arrozeira 42: 11-12.

16. Chauhan BS (2012) Weed Ecology and Weed Management Strategies for Dry-Seeded Rice in Asia. Weed Technology 26(1): 1-13.

17. SAS (2002) SAS Institute Inc. SAS/STAT software, Version 9. Cary, NC, USA.

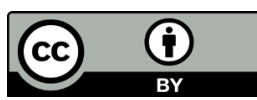

This work is licensed under Creative

Commons Attribution 4.0 License

DOI: 10.19080/ARTOAJ.2017.05.555673
18. Chauhan BS (2013) Effect of weedy rice variants and weedy rice density on growth and yield of two rice cultivars in the Philippines. Canadian Journal of Plant Protection 1: 28-34.

19. Naderi R, Bijanzadeh E (2012) Allelopathic potential of leaf, stem and root extracts of some Iranian rice (Oryza sativa L) cultivars on barnyardgrass (Echinochloa crus-galli) growth. Plant Knowledge Journal 1: 37- 40

20. Kwon SL, Smith RJ, Talbert RE (1991) Interference and duration of red rice (Oryza sativa L) in rice (Oryza sativa). Weed Science 39: 363-368.

21. Estorninos LE, Gealy DR, Talbert RE (2000) Interference between red rice and rice in a replacement series studies. Research Series Arkansas Agricultural Experiment Station 476: 463-468.

22. Estorninos LE, Gealy DR, Talbert RE , McClelland Remr (2005) Rice and red rice interference. II. Rice response to population densities of three red rice (Oryza sativa) ecotypes. Weed Science 53(5): 683-689.

23. Pantone DJ, Baker JB (1991) Weed-crop competition models and response-surface analysis of red rice competition in cultivated rice a review. Crop Science 31(5): 1105-1110.

24. Pantone DJ, Baker JB, Jordan PW (1992) Path-analysis of red rice (Oryza sativa L.) competition with cultivated rice. Weed Science 40(2): 313-319.

25. Eleftherohorinos IG, Dhima KV, Vasilakoglou IB (2002) Interference of red rice in rice grown in Greece. Weed Science 50(2): 167-172.

26. Siwakoti M, Tiwari S (2007) Emerging Needs of Wetlands Protection for the Conservation of Wild Rice Biodiversity in Nepal. Scientific World 5(5): 95-99.

\section{Your next submission with Juniper Publishers will reach you the below assets}

- Quality Editorial service

- Swift Peer Review

- Reprints availability

- E-prints Service

- Manuscript Podcast for convenient understanding

- Global attainment for your research

- Manuscript accessibility in different formats

( Pdf, E-pub, Full Text, Audio)

- Unceasing customer service

Track the below URL for one-step submission https://juniperpublishers.com/online-submission.php 